\title{
Moscow-Petushki of Venedict Erofeev and Pulp Fiction of Quentin Tarantino in the Context of Postmodern Thinking
}

\author{
BEATA WALIGORSKA-OLEJNICZAK
}

\begin{abstract}
The aim of the article is the attempt of reading two texts of culture, i.e. Moscow-Petushki of Venedict Erofeev and Pulp Fiction of Quentin Tarantino using the comparative approach that goes beyond the range of factual relationships, historical influences or similarities functioning in the plot. The purpose of the publication is to see both works, representing totally different semiotic systems (cinema and literature), in their mutual intertextual relationships for which the style of postmodernism constitutes the constant reference point. Most literary studies associate each of the chosen texts (but never both of them together) with postmodern thinking, therefore in my research I concentrate on the categories which are considered crucial for understanding postmodern thematic quests and the change in thinking which took place at the end of the $20^{\text {th }}$ century. I try to find out similarities existing in the structures of two texts, aesthetic ideas and tools used to express them. As a result, the interpretation focuses in particular on representations of the body shown in the American movie and the Russian "poem in prose", as well as on the problems of beauty, space and addictions, which constitute the fundamental subjects in these texts.
\end{abstract}

Keywords: Quentin Tarantino, Venedict Erofeev, Moscow-Petushki, Pulp Fiction, postmodernism

The aim of this article is the attempt at reading the Russian poem MoscowPetushki (1969-1970) of Venedict Erofeev and the American film Pulp Fiction (1994) of Quentin Tarantino, using the comparative approach that goes beyond the range of factual relationships, historical influences or similarities functioning in the plot, which means studying those cultural phenomena in their mutual intertextual relationships and generating new unknown levels of their perception. The style of postmodernism, understood here as the specific frame for the planned interpretation, constitutes the constant reference point in the process of our contextualization. Our choice finds its justification in literary studies associating each of the chosen texts (but never both of them together) with postmodern thinking (Kuznetsov 1997: 458; Charyn 2006: 92). One can 
come to the conclusion that postmodernism - known for its "emancipation from spirituality" and domination of extensively developing technology over "folding-in culture" (Gehlen 1963: 313) - functions in the process of our interpretation as a kind of mirror, through which we look at the selected texts of culture during the process of analysis deliberately profiled in this way. As a result of such an approach, the purpose of the publication is to concentrate on the categories which are considered crucial for understanding the postmodern change in thinking, in particular on representations of the body shown in two different semiotic systems (cinema and literature), as well as on the problem of beauty, space and addictions, which constitute the fundamental themes in the movie and the poem. The justification for the intertextual interpretation planned in this way is, first of all, the montage structure of Tarantino's film and Erofeev's poem signaling the similarities between those works of art even on their surface level, the collage aesthetics of postmodernism and the nature of hermeneutic reading of texts which allows crossing the borders of disciplines and traditional allocation of terminology.

Applying the aforementioned methodology we deliberately resign from the detailed description of the specifics of the development of Russian postmodernism and its comparison to the tendencies occurring in the West, as well as from the chronological presentation of main concepts, authors, events and initiatives, which influenced the character of this intellectual unrest. This approach is motivated by the abundance of easily accessible sources presenting postmodernism from the perspective of facts and names such as e.g. S. Kuznetsov's Postmodernism in Russia, B. Baran's Postmodernism or I. S. Skoropanova's Russian Postmodern Literature, to name just a few examples. Instead, it could be metaphorically said that the analysis is aimed at creating the specific mental map of crucial associations of ideas inspired by "dismantling" of the chosen texts, which shall reveal the nature of postmodern thinking encoded in their montage structure.

It is worth mentioning that since the very beginning the problem of body was the focus of attention of not only anatomy but of comparative studies as well. One of the first comparative works of arts - namely Érotique Comparée of Charles de Villers published in the $19^{\text {th }}$ century - showed the difference between German idealistic concept of love and sensual love of the French, noticeable in the lyrics of the $17^{\text {th }}$ century (Bilczewski 2010: 198), emphasizing that at the stage of formulating methodology comparative research was mainly interested in creating a broad picture of the phenomenon, which meant finding global, not local tendencies, emphasizing what was typical and repetitive rather than exceptional or extraordinary. Consequently, the contemporary language of the discipline of literary and cultural comparative studies was shaped on 
the common ground of theatrum anatomicum and theatrum comparativum (Bilczewski 2010: 199). Today's distinctive character of comparative studies was greatly influenced by the prestige of the biological sciences of that time, the intensification of genetically oriented projects, the attempts to merge science and history in the spirit of Charles Darwin or the epidemiological theory of culture (to name just a few examples). Although comparing information transfer with mechanisms of virus infections, which means in a sense connecting the discourse of physiology with the theory of reception, may lead to extreme emotions, it makes us aware that in the Western tradition, as early as Aristotle establishing the cathartic dimension of aesthetic experience, merging art/ culture and natural sciences has always been widely present. In the face of globalization challenges we tend to see, first of all, the transient nature of the world, the lack of stability, the liquidity and discontinuity of phenomena, which correspond with and are reflected in contemporary theories of understanding. A work of art such as Hans-Georg Gadamer's fusion of horizons, concepts of Umberto Eco and Gayatri Chakravorty Spivak's translation studies, constitute both the most adequate tool for critical approach in comparative studies and the symptomatic sign of larvae times we live in - as Georgio Agamben described our era (Agamben 2010: 51).

However, historically, the contemplation of the relationship between the nature of beauty and the category of body, which will constitute the core of the reflections in the article, was associated with approaching the opposite direction, namely putting things in order, harmony, perfect proportions. The embodiments of such assumptions in the past were: beautiful music seen through the prism of mathematical calculations, the unity of Plato's three basic ideas, the medieval concept of God perceived as the only real and perfect being, reason for creation, Leonardo da Vinci's Vitruvian man, which anticipated in a way the change of perspective observed in modern times, when we turned from the contemplation of the cult object to discovering the potential of the recipient's mobilized gaze (Friedberg 1994: 29). It can be said that the $19^{\text {th }}$ and $20^{\text {th }}$ centuries - being the field of fight of various, sometimes very different concepts - declared beauty to be an almost redundant category and revamped the status of the work of art (e.g. Marcel Duchamp's proclamation of freedom of decision what is art and who is to be called an artist). Today, it is the fact of common knowledge that each act of aesthetization has its reverse anaesthetization, and the thought of Immanuel Kant, Michel Foucault, Richard Rorty, Wolfgang Welsch or Jean-Francois Lyotard shows how the living body of culture has changed over the years. The dominant features of postmodern and post-postmodern eras started to be omnivority and visibility, taking over almost all spheres and discourses of human activities. This trend is the easiest 
to notice in the language describing the condition of today's exposed body, the state which has always constituted the litmus paper of the human way of thinking at a given stage of cultural development.

The language of gesticulation - treated by Étienne de Condillac over 200 years ago as the language of nature, the first and the most true one, the matrix for the creation of all other systems of coding - shows that the $19^{\text {th }}$ century hid the entire sphere of physiology behind the sphere of public life pronouncing the family the basic institution suppressing human instincts. Postmodernism, on the other hand, treated here as the specific trend in thinking and creating literature and art, rooted in the context of social and political changes at the end of the $20^{\text {th }}$ century, and the chronological background of our discussion of two different works of art, seems to "spit out" all the dirt, manifesting itself in shocking images of bloody violence, flesh and common consent for all kinds of excesses.

On the level of general reflection, it can be noted that art, film and literature became the space of experience of the real human body, which, on the one hand, transfixes the audience with the images of the artificially trained body, on the other hand, exposes the pictures of corporeal degradation, suffering and humiliation. Postmodernity, localizing itself against all possible standardization or objectivity (or metanarratives if we use Jean-François Lyotard's terminology), can be defined as the continuous carnival of signs which, in the field of film culture, leads to the replacement of the patriarchic hero with the ironic one. The new hero is often characterized by the crisis of his male identity, which can be encoded with the use of the language of traditional female representations and perceived as the incentive to voyeurism and moral pornography, which are understood as trivialized visualization of death and suffering, the feature regarded as the negative consequence of the aggressive consumerist society. This quality, which can be traced also in the deep layers of Moscow-Petushki, signals that following the mentality of St. Thomas and belonging to the culture of the cool (as critics describe the artistic world of Tarantino's films) (Dawson 1995: 139), the society moved far away from the ascetic ideal and calm beauty of Russian icons, the reality in which embarrassment and self-control were valued and appreciated. The adequate attitude towards the world started to be Zygmunt Bauman's concept of the tourist (Bauman 1998: 25), which can be understood as the successor of Baudelaire-Benjamin concept of flâneur, the player collecting the experiences, who is not able to appreciate the pastime of homo ludens and is fully satisfied with simulacrum - as Jean Baudrillard described the phenomenon.

This sad tendency can be easily recognized in the humanoid sculptures of the Polish artist Magdalena Abakanowicz (e.g. The Unrecognised Ones, Agora), 
which are the visual metaphors of anonymous life in a human herd. They seem to confirm the sociological diagnosis of José Ortega y Gasset, who many years ago called the entire art of the $20^{\text {th }}$ century the representation of terminus a quo (Ortega y Gasset 1968: 31), meaning the manifestation of the aspect of human existence which has been destroyed and degraded. Abakanowicz's sculptures may be perceived as the closure of the chapter of the rustic beauty civilization and the announcement of the beginning of the junk era in culture, the era of the breakdown of the symbiosis between the subject and the object. This characteristics is noticeable in the most distinctive way at the turn of the 1950s, when the revolution of the object is started by the inflow of readymades, objets trouvés, collages, assemblages, mail art and geo-art (Przybylski 1999: 352). Objects freed from their functions become the emblems of humans being trapped by the things totally devoid of the metaphysical. Abakanowicz's sculptural visualizations seem to signal the expectation of these anti-humanization tendencies, they seem to point the viewer to the direction the world of art is approaching, namely the limitation of all representations in favor of pure concept and transcendence, as well as fascination with ugliness and disintegration of the spiritual and physical. It can be said that this kind of logic is somehow continued in the futuristic language of protest and anarchy of postmodern literature.

The deep reading of Venedict Erofeev's poem Moscow-Petushki can lead to the conclusion that in his text there is a special link between the physical (inner) and the outside reality. The irradiation of the alcoholic motif is the reason for the physiology being the focal point, the sphere well known to the reader, through which he is offered the insight into the chaotic element of the outside world. Erofeev seems to utilize in this context the anthropomorphic code, which means he models the Cosmos using the aspects of physiology, in other words, creates the big picture with the images of the small world of the human body. The mediating tool is, among other things, the palette of primary colors: white, red and black, the colors corresponding to the basic products of the human body, namely milk, blood and secretions. It could be said that Erofeev uses here the catalogue method as the colors function not as decoration or visual background, de facto not being involved in the course of events, but they are inventoried, ascribed to certain subjects or objects. Erofeev's inventory of colors in terms of intensity constitutes the opposite of Anton Chekhov's theatre of nuances and halftones; it is created by dynamic "movements of the brush", the chromatic palette resembles more the one of expressionists. The specific counterpoint to these images is created by the visions of the body of the imagined lover of the protagonist Venya. They are fragmented, isolated, seldom shown in a long shot, but mostly diffused and 
listed in gradation, bringing to mind René Magritte's picture The Eternally Obvious. The separated images of female bottom, stomach, eyebrows motivate the reader to do the puzzle, the pieces of the body serve here also to build up the atmosphere of Petushki, the paradise which cannot be reached by Venya. The gradation of the fragmented body images, corresponding to the gradation of vulgar epithets describing the woman, constitutes the counterpoint to the emotional condition of the protagonist. The vividness of the physical is exchanged for the spiritual condition of the character, shown in contrast with the depressing and hostile image of Moscow.

If we were to analyze the representation of the city itself, see it in the montage network of cultural associations, it would turn out that both in Erofeev's poem and Tarantino's film the sphere of particular meaning-creating potential is the semantic area of movement, characterized by unique "fluidity" such as passages, gates, elevators, halls etc. They reveal not only the social conditions of the inhabitants' lives, but - first of all - the social and cultural conflicts they have to face. Dealing with the space exposed in the mentioned works of art, which can be defined as unfriendly or even hostile, allows us to observe the common - for both texts - tendency for the exchange of acoustic impressions by visual ones, long shots by close-ups, and the presence of sharp literary and film montage cuts, supplemented by rapid changes of the angle of (virtual) camera. In consequence, the space that is visualized makes the impression of being fabricated or duplicated, it seems to be based on the "copy/ paste" rule (especially in Pulp Fiction). At the same time it is worth noticing that both texts tend to present artificial, imagined worlds, which refer the viewer to the nostalgic pictures of the past, dominated by caricatured or simplified portraits of the characters, whose physiology and behavioral sphere can be associated with the style of carnival depictions. The exaggeration of the theatricalized gestures of the characters, which resemble the manner of comedia dell'arte, and the particular avocation for corporeal and material "bottom" similar to the style of François Rabelais, turn attention, on the one hand, to the conventionality of the presented worlds, yet on the other reveal the hidden two-vector-relationship between the high and the low, the deep gap between the outer and the concealed reality. The city may lead the recipient also to the mythologem of the road, which - in Moscow-Petushki - is understood as the act of permanent setting off, constantly being on the move, travelling across topographica sacra. In Pulp Fiction though, the road is precisely defined by the horizontal direction and the final task which has to be carried out. The viewer's emotional roller-coaster, which is created by Tarantino due to his use of suspense, leads in a way to the mechanization of the perception process, the effect which is obtained, among other things, thanks to the introduction of the stylistic 
solutions associated with the aesthetics of comic strips. The techniques used by Tarantino in order to get those results are: "black screens", pauses which could be treated as a parallel to Erofeev's "white boards", i.e. visual announcements of stations breaking the flow of a narrative; the method of visual redundancy or creating characters who are inspired by popular myths and conventions known from cartoons. The characters of both texts which are interpreted in the article can be perceived as the key that motivates general reflection on the culture of America and Russia. Taking into account the deep symbolism of Los Angeles, which is saved in cultural memory, one should also consider the dichotomy of the cities Moscow and Petushki - brought to the attention of the recipient even by the title of Erofeev's poem - whose polar perception could be, to a certain extent, questioned during the thorough interpretation of the poem. However, proving this assumption needs further, and much deeper, research studies going beyond the aims of this publication.

The sense of sight activated in the process of perception of the selected works of art leads us to the semantics of colors dominating in Tarantino's body images. They turn out to be similar to the Erofeev triad of white, black and red. These primary colors in Tarantino's work can also be associated with the poetics of the comic strip as the director utilizes the tools traditionally attributed to this genre in the sphere of visual expression and the methods of character construction The listed colors in the context of American culture obviously lead the viewer to the still existing problem of racism, fight for power and supremacy as well as to the changing identity of the black male body, encoded in the montage of sequences presenting Marsellus, the controlling figure of the mafia boss. Tarantino seems to treat black as the code of dominance using the stylistic means of synecdoche, pars pro toto, in close-ups of the back of Marsellus's head, images of his beautiful but totally dependent wife or caricatured and ironic figure of Butch, the boxer epitomizing the white colonizer. Even the scene in the pawn shop in which the recipient sees the degraded body of the gangster resembling a rag doll, which could be interpreted in the view of the antic theory of hestos as the dead body, ends with Marsellus gaining the lost control (Waligorska-Olejniczak 2013: 142). The meaning is expressed in the character's resuming vertical position and stylized shots of violence picturing theatrical gestures of slavery masters, familiar to the viewer also from the latest Tarantino's film Django Unchained.

It is worth pointing out that the scene of rape as well as many other emblems of violence in Tarantino's film is introduced as its reverse. I mean here that the viewer is aware of its brutality but the camera avoids its visualization. On the level of montage the visual is replaced by the audial to lead to the final shock of the recipient. This feature allows us to position Tarantino's text in the 
main current of the postmodern cinema, which is famous for visualizing the delight with training the human body and long spectacles of physical tortures and death. This tendency could be diagnosed as the change from traditional memento mori into caricatured and nightmare memento vivere (Miczka 2013: 187). Tarantino, who is considered the patron of ultraviolence, however, in most cases avoids vivisection and spares the viewer turpism and shocking details of brutal procedures, presenting instead the final results of violence such as blood spread all over the car or unrealistic body of a dead person resembling a doll, leaving the most drastic visions to the imagination of the spectator, treated by him as the witness of the screen violence. In the past, violence could appear in a film only at certain moments which were established by the classic cinema convention. In such cases the viewer was prepared and taught to expect some brutality. In Pulp Fiction violent shots are additionally emphasized by the interference (on the level of the artistic world) of the elements of the real world, which sharpens the artificiality of those film mechanisms, localizing the work in the context of grotesque and black comedy, allowing building up distance to violence. On the other hand, though, moral anxiety and shock experienced by the viewer may prove his indifference, which could be compared to the medieval excitement of the crowds known from Rabelais's prose. As Marsha Kinder noticed (Kinder 2001: 79), once the viewer was ashamed of his pathological fascination, in case of Tarantino's films he is ashamed of his ability to actually have fun while watching events commonly associated with seriousness and sadness.

It seems that in Tarantino's and Erofeev's texts the body in its physical and physiological presence constitutes the basic sphere of the evaluation of the low (profanum) through its relationship with the high (sacrum). The wide range of motifs encoded in the language of the corpora includes the provocative invitation for the metaphysical game with the recipient, and the specific character of the montage composition of those works of art allows making this game real. The central sphere depicting this rule is built up by the clashes of shots referring the recognizing subject to the physiology of digestion, various kinds of discharges, odors or tastes. Described by critics as pulpophile, Tarantino uses in this area double coding, bombarding the audience with both verbal and visual information about the characters' needs to relieve themselves (noticeable in the behavior of Honey Bunny and Vincent) and takes advantage of those motifs to impart a sense of parody, which again could be read as the imitation of Rabelais Pantagruel's laughter. Repetition of the anal element in different visual and verbal configurations refer to the primitive, naïve or immature, to the world of the child, if the motive is read through the psychology of Jean Piaget, according 
to whom the first phase of child's development is sensory-motoric, meaning that he or she experiences the world mainly through the physical.

The association with youth and freshness also builds up connotations with American culture, so much focused on the corpora, which seems to be emphasized in Tarantino's famous adrenaline shot or Butch's story of the watch, passed from generation to generation. The latter starts with the exaltation of the object treated almost as a holy relic to be finally replaced by the grotesque episode of Vietnam war dysentery, a change which could have been inspired by Rabelais' images of material and physical bottom. Tarantino's montage solutions seem to be, in a way, a mirror image of Erofeev's strategy. The director also seems to make use of the anthropomorphic code, which was mentioned at the beginning of the interpretation. However, the corporeality of Venya constitutes the sphere of intimacy and shame, Pulp Fiction - a contrario is closer to the carnival freedom of rolling around in the mud. Using this strategy by Tarantino could be seen as an attempt to build up a distance to the sphere of the physical as well as a motivation to question the credibility of the American cult of national heroes and beauty of a young body.

The alluring picture of the clean and pampered body can also be discussed from the perspective of the stereotypes of racial segregation. The ideal body may become the localization of fear, hatred and prejudices, therefore one of the ways to overcome the problem - according to Richard Shusterman, one of contemporary philosophers of corporeality - could be the notion and awareness of the fact that the nature of all bodies is contaminated and dirty (Shusterman 2010: 177). Reading Tarantino's film in the light of Ludwig Wittgenstein's somaesthetics, which is highly valued by Shusterman, we could treat shocking manifestations of bodily secretions as the reference to the American faith in the cultural melting pot, metaphorically understood as extending borders of all bodies which are mutually assimilating and absorbing each other as a result of the continuous merging of cultures, being simultaneously enriched and destroyed during the process.

The physiological being of Erofeev's character could be placed on the opposite pole of the extraverted American syndrome, although, initially, the range of expressions describing his health complaints, crudeness of the language and of his imagination, resembling the manner of folk storytelling, may make a totally different impression. The problem of Venya can be defined as being inadequate and permanently misunderstood in the entropic reality of Soviet Russia, but his attitude cannot be contained in a simple bi-polar relationship of sacrum and profanum. The rule of the reverse reading which would rely on replacing the vulgar with the subtle does not seem to work out here. This kind of mental exchange could be even dangerous as the sensitive nature of the 
protagonist could be positioned - as a result of such a method - in the sterile space of the totalitarian utopia, commonly associated with the cleansings of the system governed by Moral Code of Communism Builders. In some respects this totalitarian way of thinking could constitute the parallel of the postmodern treatment of the body, which is to be subjected to various kinds of drills and deprived of its right to become old and imperfect. This paradox may explain the use of travestied biblical language in Moscow-Petushki, especially in situations which are incompatible with the solemnity of this code. However, the nature of this intertextual relationship is a very broad and complex issue, which has already been widely worked out in the academic discourse, so it seems justified to leave it on the margin of our discussion (Supa 2006: 9-30; Simmons 1993: 57-90).

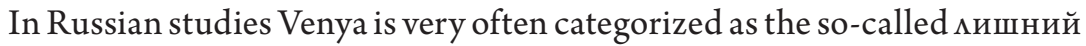
чемовек, the superfluous man (Geisser-Schnittmann 1989: 15), localized in the peripheral area. In his case it means that he does not accept the artificial world of socrealism, the world of norms, decrees and regulations, which are parodied in the discussed work of art. On the other hand, he is also against the pantagruelian reality of obscene laughter, animal instinct and visibility of biological reflexes, although the sphere of physicality plays the role of a matrix, the constant value the entire chaos of everyday life is referred to. Physiology is used in a manner of synecdoche supplementing the close-ups of the details of physiognomy or behavioral sphere of characters, therefore they are often perceived by researchers in the context of Mikhail Bakhtin's theory of carnivalization, Mikhail Epstein's vision of post-carnival or their negative realization (Epsztejn 1994: 302) as the pro tempore aspect of carnival is not able to develop in the artistic reality of Erofeev.

The comparative nature of the interpretation encourages us also to work out the chain of body-focused associations in the context of the philosophy of the Far East, which, on the deep level of understanding, seems to show great affinity with the Russian culture and religion. Far Eastern symbolism can be activated as the focal point of the interpretation of Pulp Fiction, for example in the reading of the sequence of the samurai-style gesticulation of Butch. However, the episode leaves the viewer rather with the image of ersatz, a simplified and ironic treatment of the bushido code, which is known from popularized versions of kung $f u$ movies. A wide range of motives encoded through the sphere of corporeality can be read as a type of provocative invitation to engage the recipient in a metaphysical game, turning attention to the similarities between the language of the works of art and the collage logics of postmodernism and contemporary aesthetics. The procedure of "the extended" body representation of the American director allows perceiving it as 
a kind of projection of the culture which is slipping out from the control of the white colonizer, the culture with its central position of homo eroticus, i.e. the human being finding the harmony of existence in the physical grounding in his body. The visual similarities of the reificated body images - which are present in both discussed texts - can lead the recipient also to the contemplation of the problem of desacralization of the former taboo spheres.

The meeting of Russian and Japanese culture could be situated in the context of the ideal of the ascetic body, associated with the strict canon of human body representations of Russian icons and the code of koan, familiarized and modernized, for example, by Jim Jarmusch in his Ghost Dog. It can be noticed that the literary visions of Venedict Erofeev cannot confirm this quality of the Russian character, the reader de facto metaphorically balances between the excess of alcoholically stimulated complaints and the lack of alcohol, resulting in suffering and loss of dignity, missing somehow the point of moderation. The protagonist cannot actually find the midpoint, from the perspective of his praxis he is against both approaches - extreme hedonism and total asceticism - he positions himself somewhere between those opposites. One could metaphorically say that he seems to locate himself not at the point of symmetrical distance to those options but rather at the point of choosing negations of both positions.

The core topos which can be perceived in the function of leitmotiv of Tarantino's and Erofeev's works of art is definitely the problem of substances, namely alcoholism and drug addiction, the interpretation of which reveals the aspect of non-verbalized search for the Whole in both texts. Addictions of the characters serve as a medium to create alternative realities, ritualize situations and change chaos of their lives into the experience of the Cosmos. The motif of drug addiction in Pulp Fiction could be understood as the act of individual protest against the limitations of the Western system of values. Such a type of perception may emphasize the contrast between the communitycentered character of Russian culture, enrooted in the spirit of theology of the Russian orthodox icon, and "the lightness of being" of the American culture of the individual. The contexts that could be evoked in further analysis of the problem of addictions, i.e. mythical, ritual and carnival, create an opportunity of understanding the behavioral sphere of characters as the manifestations of the rituals of passage, experiences of liminal time, signifying the cultural dialogue between the mentality of the East and the West, which takes place in the discussed texts.

The ideas presented in this article constitute only a minuscule part of the comparative interpretation of the selected texts in the context of postmodern thinking. Starting with the broader, partially historical outline of the category 
of beauty in reference to body and finishing with more analytical point of view I wanted to show that literary studies, in particular comparative literature studies, help us to reach the level of a molecule in the process of world observation and interpretation. This molecule can be treated as the starting point to move in the intertextual net of contemporary disciplines as well as to reach the deep level of understanding of the symbolic nature of the world. The category of body perceived as signum temporis marks postmodernity as the time of provocative changes and challenges and leaves the recipients of texts with the open question whether the postmodern images of violence, physiology or body degradation can still lead him to the refreshing experience of catharsis. Besides, the analyses conducted in the article make it visible that we need to define a new formula of being in the face of epochal challenges; we have to search for a definition of an updated paradigm for the literature and art of the current century. It seems that the core value, the so-called zero point of the paradigm search on the Russian ground should constitute the eternal problem of being trans, the process of struggling with difficulties, which is not evaluated by the value of reaching the destination but rather by the continuous being on the road, fighting, suffering and surviving. The perfect equivalent of this almost genetic Russian feature in American literature could constitute the phenomenon of the continuously moving frontier, the native category shaping cultural and national identity of the US citizens.

\author{
Beata Waligorska-Olejniczak \\ beata.waligorska@amu.edu.pl \\ Uniwersytet im. Adama Mickiewicza w Poznaniu \\ Instytut Filologii Rosyjskiej \\ al. Niepodległości 4 \\ 61-874 Poznań \\ POLSKA
}

\title{
Bibliography
}

Agamben, G. 2010. Nagość. Trans. K. Żaboklicki. Warszawa: WAB.

Baran, B. 1992. Postmodernizm. Kraków: Inter Esse.

Bauman, Z. 1998. Globalization: The Human Consequences. New York: Columbia University Press.

Bilczewski, T. 2010. „Theatrum Anatomicum”: komparatystyka i ciało. - E. Szczęsna, E. Kasperski, eds. Komparatystyka dzisiaj. Problemy teoretyczne. Kraków: Universitas. 
WALIGORSKA-OLEJNICZAK

Charyn, J. 2006. Raised by Wolves: the Turbulent Art and Times of Quentin Tarantino. New York: Thunder's Mouth Press.

Dawson, J. 1995. Quentin Tarantino: The Cinema of Cool. New York: Applause Books.

Epsztejn, M. 1994. Po karnawale, czyli Wieczny Wieniczka. - Literatura na Świecie, $7 / 8,302-329$.

Friedberg, A. 1994. Window Shopping. Cinema and the Postmodern. Berkeley-Los Angeles-London: University of California.

Gehlen, A. 1963. Studien zur Anthropologie and Soziologie. Neuwied: Luchterhand Verlag.

Geisser-Schnittmann, S. 1989. Venedikt Erofeev „Moskva-Petushki”, ili „The rest is silence". Bern: Peter Lang. = Гайсер-Шнитман, С. 1989. Венедикт Ерофеев „Москва-Петушки”, или „Тhe rest is silence”. Bern: Peter Lang.

Kinder, M. 2001. Violence American Style: The Narrative Orchestration of Violent attractions. - D.J. Slocum, ed. Violence and American Cinema. New York: Routledge.

Kuznetsov, S. 1997. Postmodernism in Russia. - H. Bertens, D. Fokkema, eds. International Postmodernism. Amsterdam-Philadelphia: J. Benjamins.

Miczka, T. 2013. O śmierci na ekranie, Katowice: Śląsk.

Ortega y Gasset, J. 1968. The Dehumanization of Art and Other Essays on Art, Culture, and Literature. Princeton: Princeton University Press.

Przybylski, R. 1999. Prześwit między przedmiotami. - B. Kaniewska, S. Wysłouch, eds. Człowiek i rzecz: o problemach reifikacji w literaturze, filozofii i sztuce. Poznan: Wydawnictwo Naukowe UAM.

Shusterman, R. 2010. Świadomość ciała. Dociekania z zakresu somaestetyki. Kraków: Universitas.

Simmons, C. 1993. Their Fathers' Voice. Vassily Aksyonov, Venedikt Erofeev, Eduard Limonov and Sasha Sokolov. New York: Peter Lang.

Supa, W. 2006. „Biblia” jako intertekst w poemacie Wieniedikta Jerofiejewa „MoskwaPietuszki”. - Studia Wschodniosłowiańskie, 6, 9-30.

Waligorska-Olejniczak, B. 2013. Sacrum w drodze. "Moskwa-Pietuszki" Wieniedikta Jerofiejewa $i$ „Pulp Fiction” Quentina Tarantino w kluczu montażowego czytania. Poznan: Wydawnictwo Naukowe UAM. 